\title{
COMPARISON OF THE SEED BANK WITH THE ABOVEGROUND VEGETATION OF FIELD WEEDS IN THE NEIGHBOURHOOD OF MIKULOV IN SOUTH MORAVIA
}

\author{
M.Zdražílková
}

Received: May 5, 2010

\begin{abstract}
ZDRAŽÍLKOVÁ, M.: Comparison of the seed bank with the aboveground vegetation of field weeds in the neighbourhood of Mikulov in South Moravia. Acta univ. agric. et silvic. Mendel. Brun., 2011, LIX, No. 1, pp. 277-290

The processed set of phytosociological relevés indicated that at the present time the field weed associations are composed particularly of species of wide ecological amplitude. The rare and endangered species appeared only on localities usually not much affected by chemicals. Most of the endangered species of field weeds were found to survive primarily on small private farms, in the headland of fields or on field edges near the natural reserves.

The results indicated that the type of crop had a significant effect on the composition of the current aboveground vegetation. There is a close relationship between the type of crop and the applied cultural practice. Its effect is much more important than the effect of the overall method of management. However, long-term application of herbicides may eliminate some weed species from the seed bank and as a consequence also from the current vegetation. That is the reason why crop rotation is so important for preserving the species diversity of weeds in tandem with limited applications of herbicides.
\end{abstract}

soil seed bank, aboveground vegetation, weeds

On arable land the supply of weed seeds is very important because an excessive presence of weeds has also an economic impact. In agricultural practice the seed bank is most frequently used as an indicator of the quality of agricultural measures or to compare the effects of various crop rotations, soil tillage technologies or weed control. ing:

The objectives of the present study are the follow-

1. Basing on comparisons between the current vegetation and the soil seed bank to evaluate the present state of field weed associations.

2. Compare sites under various methods of management.

For our studies we selected an area in South Moravia between the river Dyje and the border with Austria of approximately $330 \mathrm{~m}^{2}$. In terms of the climate this region belongs to the driest and warmest regions of the Czech Republic.

\section{MATERIAL AND METHODS}

\section{Soil seed bank}

In order to study the plant associations in the fields or on ruderal sites the soil should be sampled at the time when the winter species have finished germination but before the seeds have matured and seeded out (Warr et al., 1994), i.e. in winter or early spring. Samples collected in summer contain freshly seeded out seeds of winter species and this distorts the image of the quantitative composition of the seed bank.

Basing on observations of the vegetation during the vegetation period we selected 11 sites for soil sampling in the autumn (October) of 1997. The next samples were taken in spring (March) and autumn (October) of 2002. On top of that, another 11 sites were selected in 2002 where two mixed samples were taken from each site in spring and in autumn. 
Based on the method of management the land was divided into three categories:

1. private - private plots and private fields farmed by small farmers $(\mathrm{P})$.

2. large-scale farms - managed by agricultural enterprises (AE).

3. organic farming - land belonging to an organic farm $(\mathrm{O})$.

Considering that every year the entire soil layer is turned over and intermixed by ploughing and that the samples were not taken for the purpose of monitoring the current amount of diasporas in specified depths of the topsoil, the samples were not divided into partial layers. On each site an area of $5 \times 5 \mathrm{~m}$ was selected, i.e. comparable in size with the area of the phytosociological relevés, and 32 places were set out from which samples were taken from the entire depth of the tilled soil with a punch $1 \mathrm{~cm}$ in diameter (Fig. 1). All the samples were mixed up into one mixed sample. Taking a larger number of partial samples shall eliminate the effect of plant seeding out into one place.

\section{- the place of insertion with a punch}

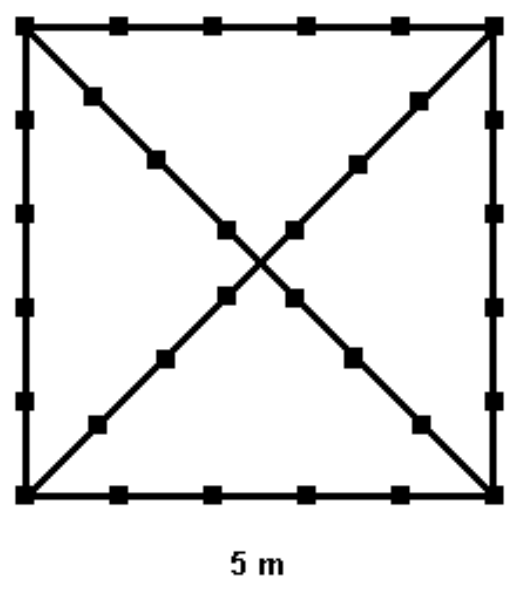

$5 \mathrm{~m}$

1: Soil sampling - distribution of insertions with a punch

The soil samples were homogenised and dried at laboratory temperature. From each autumn sample $(1997,2002)$ two times $100 \mathrm{~cm}^{3}$ of soil was taken; from the spring samples (2002) three replications of a volume of $100 \mathrm{~cm}^{3}$ were taken. On sites where soil samples were taken in 2002 only, two more replications of $100 \mathrm{~cm}^{3}$ of soil were taken from samples collected in autumn. The samples were then soaked in water $(24 \mathrm{~h})$ and washed in a flow of water on a $0.25 \mathrm{~mm}$ mesh sieve. The remaining fraction was dried at laboratory temperature and analysed. All whole seeds and fruits were separated manually under a preparation magnifying glass and the qualitative and quantitative distribution was determined.

We must not forget that the number of diasporas is considerably affected by the quantity of produc- tion by the parent plants, dissemination capacity and germinating capacity. It is therefore very difficult to convert the detected values to values corresponding to the coverage degree of species in the aboveground vegetation. This is the reason why the processed data are limited to data on the presence/ absence.

\section{Current vegetation}

During the entire vegetation period only the species composition of the vegetation was explored on all the 22 sites. Two different records were made on each area:

1. Vegetation record on an area preferably identical with the area where the soil sample was taken. (Setting out permanent areas on arable land is not possible because the land is cultivated.)

2. Vegetation record from an area where soil samples were taken and from the surroundings.

For further processing these data were also reduced to the presence/absence data.

For a better monitoring of the current state of segetal associations, 154 phytosociological relevés were recorded from 1996 to 2002 in the territory under study. The size of the relevés ranged between 5 and $25 \mathrm{~m}^{2}$ (in most cases it was $16 \mathrm{~m}^{2}$ ). In addition to standard data also the method of management was recorded for each relevé (P, AE, O).

The scientific names of vascular plants were unified according to Kubát (Kubát et al., 2002). The names of bryophytes was unified according to Frahm and Frey (Frahm and Frey, 1992). Some species were associated into aggregates prior to analysis or they were determined only at the level of genera; particularly the taxonomically problematic groups or taxons, which could not be determined more accurately in the seed bank.

\section{Data analysis}

Comparison of the vegetation with the seed bank

As environmental variables the method of management and type of relevé were assigned to the relevés of the current vegetation and seed bank from 22 of the studied localities. The variable "method of management" included three categories: agricultural enterprise (AE), private farmer $(\mathrm{P})$, organic farm (O). The variable "type of relevé" had two categories: seed bank and current vegetation.

The qualitative similarity between the seed bank and vegetation was calculated using Sörensen's coefficient. The quantitative distribution of species was not evaluated.

Multidimensional analysis was used to determine the effect of the method of management on the species composition of the seed bank and aboveground vegetation. First of all detrended correspondence analysis (DCA) was conducted with the set of relevés by means of the CANOCO 4.5 package (ter Braak \& Šmilauer, 1998). For easier interpretation of the results the environmental variables were passively interlaid into the ordination diagram (method of man- 
agement and type of relevé) together with average Ellenberg's indication values calculated for each relevé in the JUICE 6.3 programme (Tichý, 2002).

The next step was to monitor whether any change had taken place in the seed bank between 1997 and 2002 and if this change had shown a uniform trend. For this purpose we made a set of relevés of the seed bank from 11 localities from which soil samples were taken on both dates and this was subjected to detrended correspondence analysis (DCA).

Then tests were done to see if the difference between the seed bank and current vegetation was statistically significant and how the variability of the vegetation and the seed bank differed in dependence on the method of management. For this purpose the JUICE 6.3 programme (Tichý, 2002) was applied to calculate the Euclidean intervals and Sörensen's coefficients. With these values the ANOVA analyses were calculated using the Post-hoc test Turkey HSD for an unequal number of replications. The STATISTICA 7.1 programme (StatSoft 2001) was used for statistical analyses and the respective graphs.

The effect of cultural practice on the species composition of segetal associations

A set of 154 phytosociological relevés showing the current state of segetal associations were subjected to canonical correspondence analysis (CCA) where the following environmental variables were entered: method of management (agricultural enterprise, private farm, organic farm), type of crop (cereal, maize, root crop, oil crop, fodder crop, vineyard, other) and the season (continuous variable with values from 0 to 12). Using the permutation test (Monte Carlo test) we tested the significance of the environmental variables.

\section{RESULTS}

The results of analysis of the seed bank are given in Tab. I and II. The most frequent weeds occurring in the seed bank on the monitored localities were Chenopodium album agg., Amaranthus sp., Fallopia convolvulus, Chenopodium hybridum, Polygonum aviculare agg., Stellaria media, Tripleurospermum inodorum, Cirsium arvense and Papaver rhoeas, Anagallis sp. Unambiguously at the top of the list in terms of the number of diasporas found in the respective soil samples was Chenopodium album agg. and Amaranthus sp., i.e. species with a very high production of diasporas. In addition to these common widespread weeds the occurrence of rare and endangered species was also found in the seed bank, such as Adonis aestivalis, Bupleurum rotundifolium, Caucalis platycarpos, Centaurea cyanus, Hyosciamus niger, Silene noctiflora and Vulpia myuros.

The qualitative composition of aboveground vegetation on all the 22 sites shows the Tab. III. The 15 most common field weeds of the current vegetation are: Tripleurospermum inodorum, Papaver rhoeas, Chenopodium album, Convolvulus arvensis, Cirsium arvense, Stellaria media, Polygonum aviculare, Amaranthus retroflexus, Capsella bursa-pastoris, Artemisia vulgaris, Fallopia convolvulus, Viola arvensis, Consolida regalis, Descurainia sophia, Galium aparine. at sites that are not very influenced by chemical sprays do we also see rare and endangered species: Adonis aestivalis, Anagallis foemina, Bupleurum rotundifolium, Caucalis platycarpos, Centaurea cyanus, Euphorbia falcata, Galium spurium, Kickxia elatine, Nigella arvensis, Silene noctiflora.

\section{Drawing comparisons between the vegetation and the seed bank}

The values of Sörensen's indices of similarity given in Tab. I indicate that the qualitative similarity between the seed bank and the current vegetation is relatively high. If we focus on the variability between the current vegetation and the seed bank on land under different methods of management (Fig. 2) we shall see that the differences between the seed bank and vegetation are the greatest in agricul-
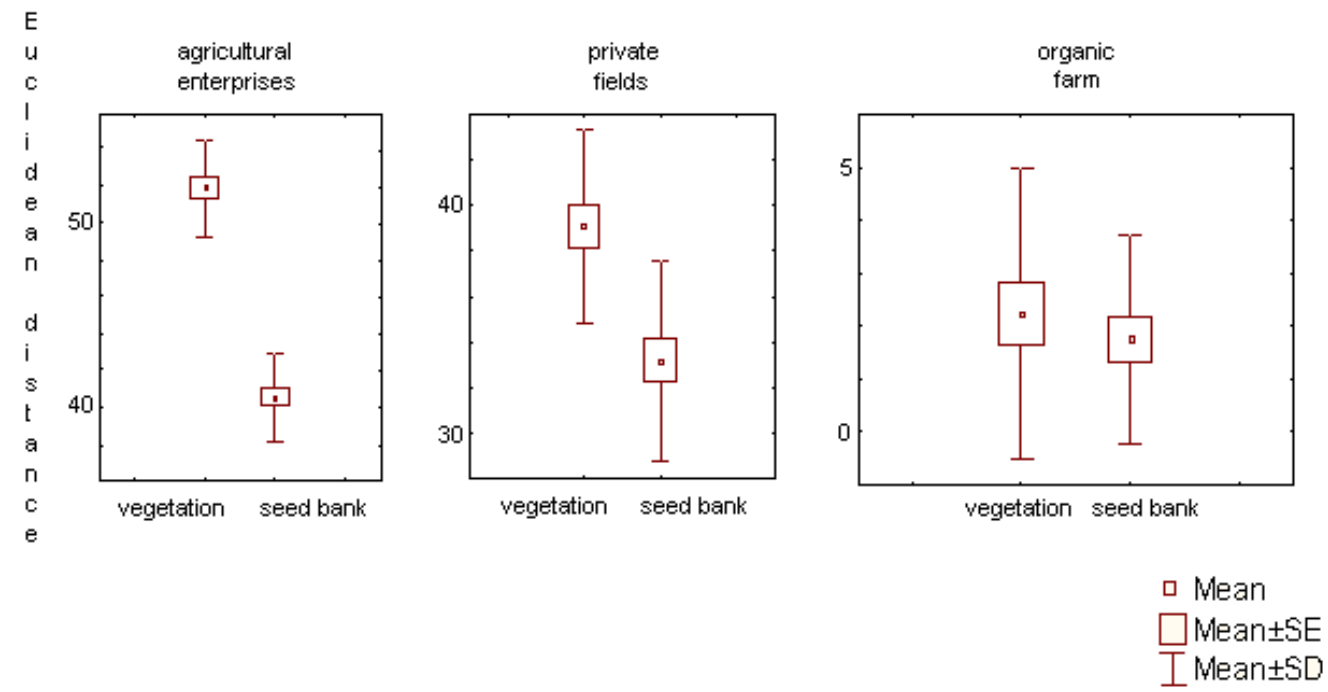

2: Variability between the current vegetation and seed bank on land of different methods of management 
tural enterprises, to a lesser degree on private farms and the least on organic farms. In terms of the average numbers of species in the seed bank and in the current vegetation (Fig. 3) we saw that the species diversity of the seed bank reflected the diversity of the aboveground vegetation and was the highest on the organic farm. When drawing conclusions we must not forget that the number of replications was not the same for all three methods of management.

The ordination diagram in Fig. 4 indicates that certain changes occurred in the seed bank in the course of five years, but they were not uniform, neither as an entirety nor within the framework of the same method of management.

Direct ordination (DCA analysis), where the presence/absence data on the current state of vegetation and on the seed bank were used as the input set (Fig. 5), showed the variability between the relevés of the vegetation and the seed bank from 22 selected localities. For better illustration the relevés related to the same locality were coupled into pairs. Different methods of management were marked off graphically. The first ordination axis (eigenvalue 0.348, total inertia 3.672 ) exemplifies the $9.5 \%$ variability. The

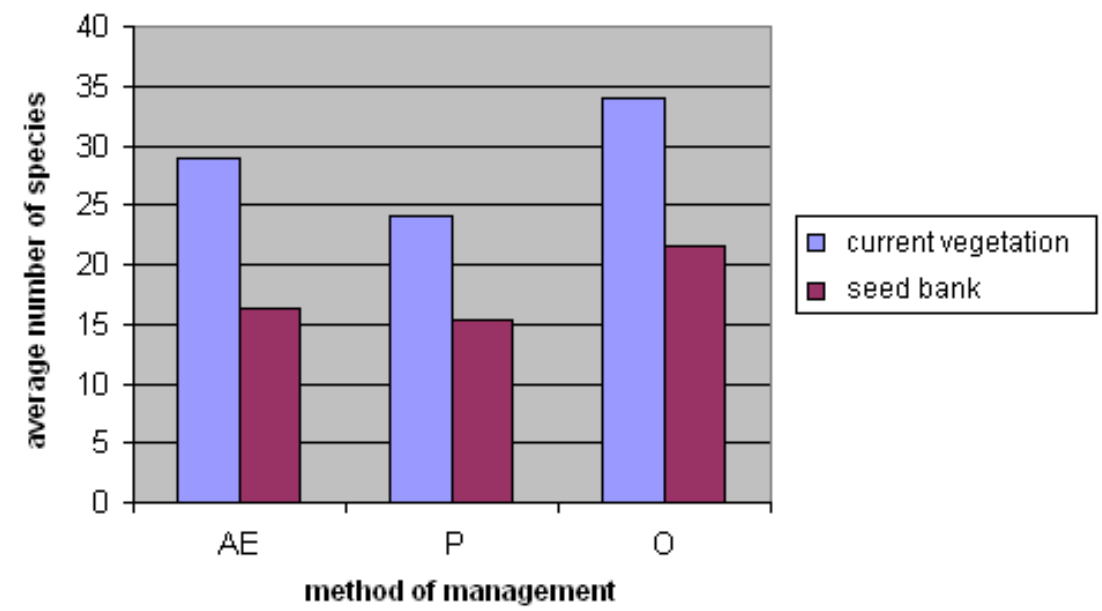

3: Average numbers of species in the current vegetation and in the seed bank on land of different methods of management

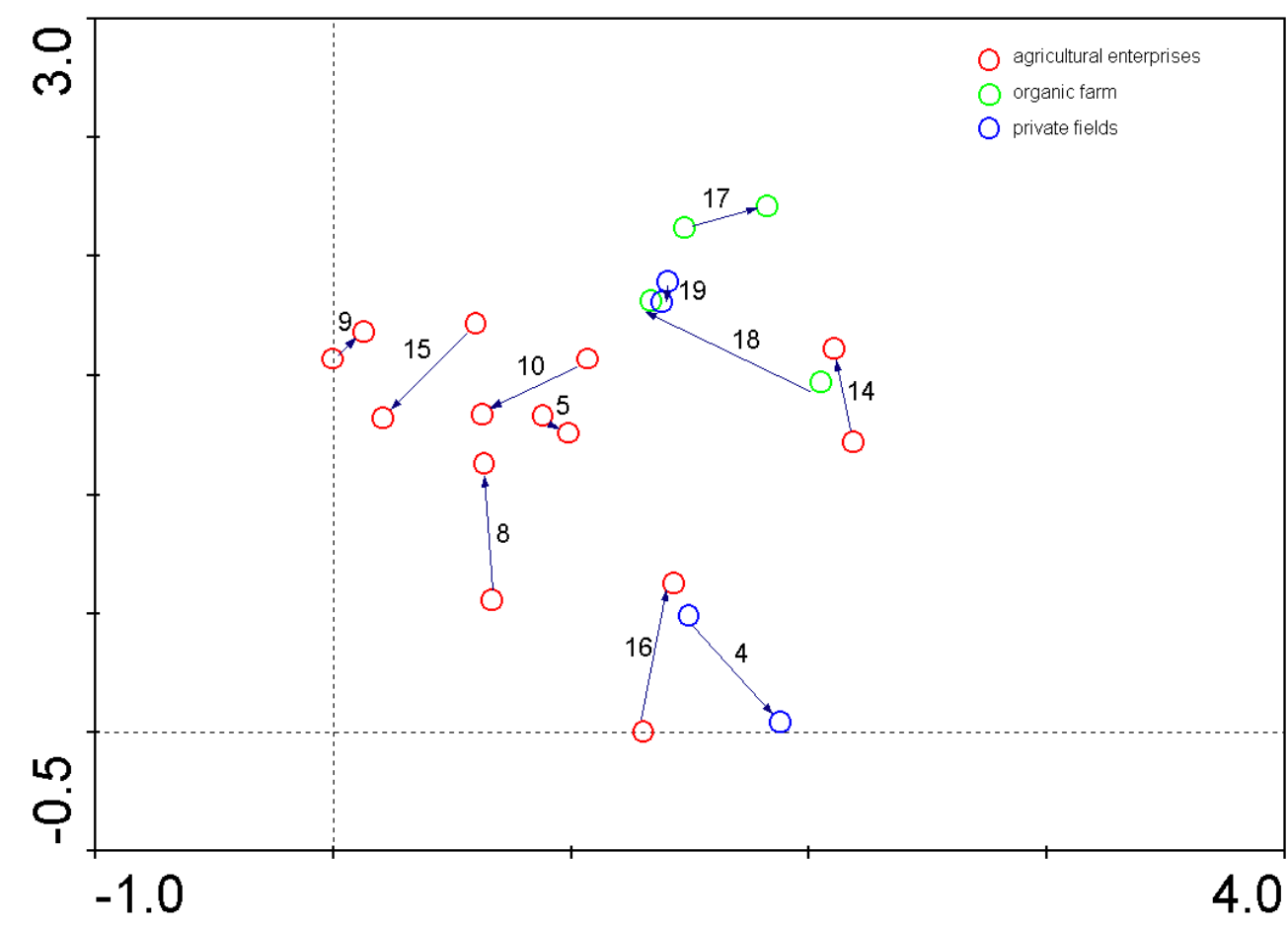

4: Detrended correspondence analysis (DCA) diagram of samples: changes in the seed bank between 1997 and 2002. Figures = numbers of localities, the arrow is headed from autumn 1997 to autumn 2002. 


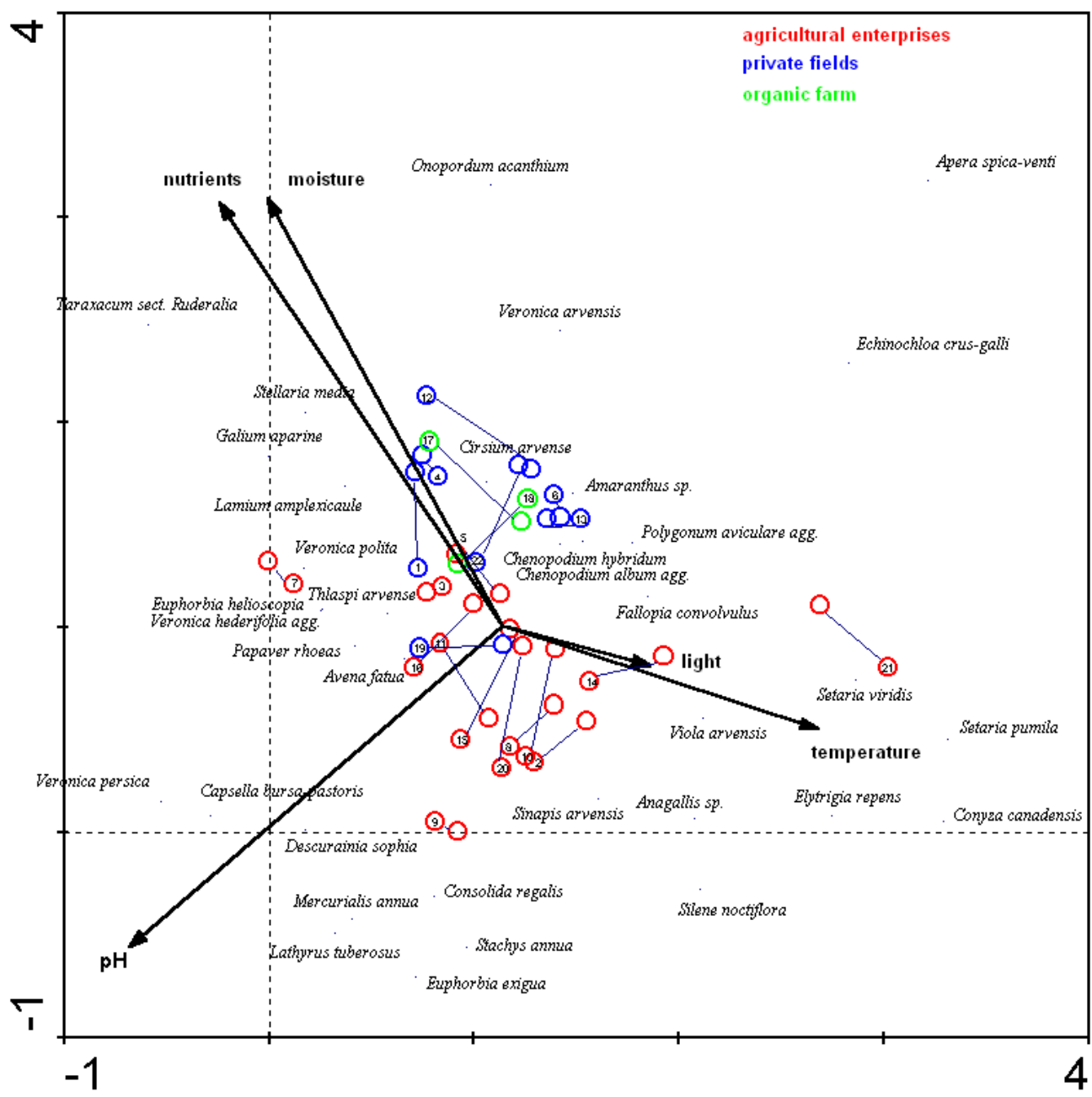

5: Detrended correspondence analysis (DCA) diagram of species and samples with passively projected environmental variables

second axis (eigenvalue 0.247) together with the first axis exemplifies the $16.2 \%$ variability. DCA analysis showed that relevés from areas managed as private farms and from organic farms were close.

The effect of cultural practice on the species composition of segetal associations

Fig. 6 gives the results of CCA analysis of a set of 154 phytosociological relevés showing the variability in the species composition of associations of field weeds. The first axis accounts for $36.3 \%$ of the total variability of data on species and corresponds with the season. The second axis accounts for the $24.7 \%$ of the total variability and is associated with other gradients of the environment. The Monte Carlo test showed the season to be the most important environmental variable, followed by some crops (vineyard, cereal, fodder crop) and only then the method of management.

\section{DISCUSSION}

If we compare the values of Sörensen's indices of similarity of the seed bank with the aboveground vegetation as given in Tab. II we can see that the val- ues are markedly higher if we are able to relate the seed bank data to concrete vegetation records; that means if the area of the vegetation record is wholly identical with the area where soil samples were taken for analysis of the seed bank. If we draw comparisons of the qualitative composition of the seed bank on a certain area and of the vegetation not only on the area of soil sampling but also in the surroundings, the indices of similarity show lower values than when the two areas are identical. It is caused by an uneven distribution of species in the aboveground vegetation and seed bank in the soil. To eliminate this difference, the area of the relevé would have to be considerably bigger and more soil samples would have to be analysed.

Fig. 2 shows that the greatest differences between the seed bank and the current vegetation were discovered in the agricultural enterprises, less on private farms and the least on organic farms. This might be caused by greater and more frequent mechanical disturbances on areas managed by agricultural enterprises, or by more frequent application of herbicides. Important is also the range of the produced crops because each type of crop requires differ- 


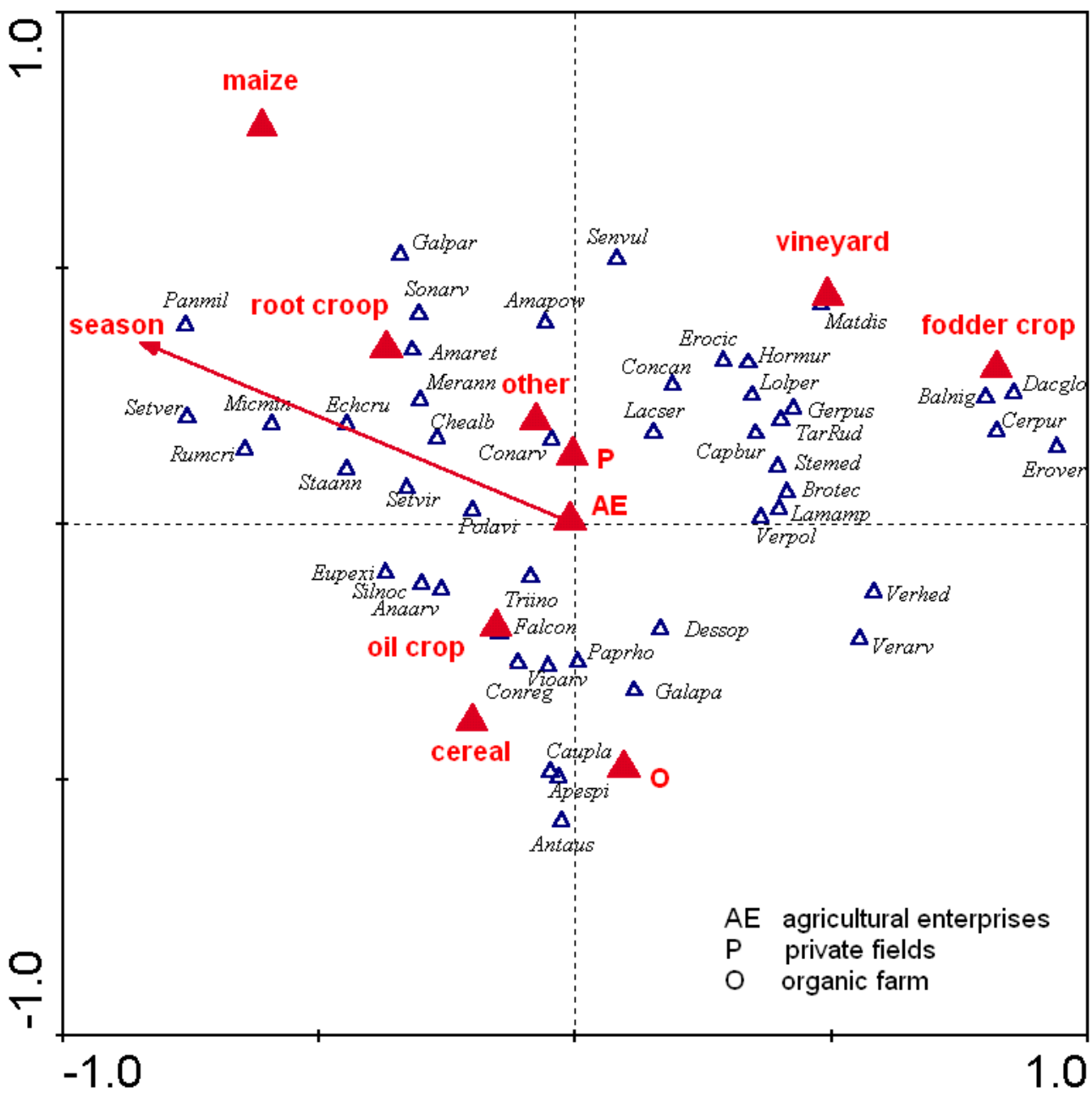

6: Canonical correspondence analysis (CCA) diagram of species with environmental variables

(Amapow = Amaranthus powellii, Amaret = Amaranthus retroflexus, Anaarv = Anagallis arvensis, Antaus = Anthemis austriaca, Apespi = Apera spica-venti, Balnig = Ballota nigra, Brotec = Bromus tectorum, Capbur = Capsella bursa-pastoris, Caupla = Cancalis platycarpos, Cerpur $=$ Ceratodon purpureus, Chenalb $=$ Chenopodium album agg., Conarv = Convolvulus arvensis, Concan = Conyza canadensis, Conreg = Consolida regalis, Dacglo = Dactylis glomerata, Dessop = Descurainia sophia, Echcru = Echinochloa crus-galli, Erocic = Erodium cicutarium, Erover $=$ Erophila verna, Eupexi $=$ Euphorbia exitus, Falcon $=$ Fallopia convolvulus, Galapa $=$ Galium aparine, Galpar $=$ Galinsoga parviflora, Gerpus = Geranium pusillum, Hormur $=$ Hordeum murinum, Lacser $=$ Lactuca serriola, Lamamp = Lamium amplexicaule, Lolper $=$ Lolium perence, Matdis $=$ Matricaria discoidea, Merann = Mercurialis annua, Micmin $=$ Microrrhinum minus, Panmil = Panicum miliaceum, Paprho = Papaver rhoeas, Polavi = Polygonum aviculare agg., Rumcri $=$ Rumex cricpus, Senvul $=$ Senecio vulgarit, Setver $=$ Setaria verticillata, Setvir = Setaria viridis, Silnoc = Silene noctiflora, Sonarv = Sonchus arvensis, Staann= Stachys annua, Stemed = Stellaria media, TarRud = Taraxacum sect. Ruderalia, Triino = Tripleurospermum inodorum, Verarv $=$ Veronica arvensis, Verhed $=$ Veronica hederifolia agg., Verpol = Veronica polita, Vioarv = Viola arvensis. $)$

ent agricultural measures. Mayor \& Dessaint (1998) drew the same conclusions.

It must be taken into account that the weed vegetation existing at a certain period of time on a certain site is only a partial representation of the potential flora. Many species differ in their seasonal distribution of seedling emergence, and that means that the species composition is affected by the season of the year, in which the soil was disturbed.

In their evaluation of factors affecting the species composition of field weed associations Lososová et al. (2004) reached the same conclusions. In their opinion the most important factor is the altitude followed by the seasonal dynamics and type of crop. In my present study the influence of the altitude was not very important because the phytosociological relevés were recorded within a small range of altitudes (170-320).

The assumption that associations with the greatest abundance of species having a much higher proportion of rare and endangered species would develop on localities of organic or private farms was not proved. 
I: The qualitative komposition of soil seed bank-presence/absence data

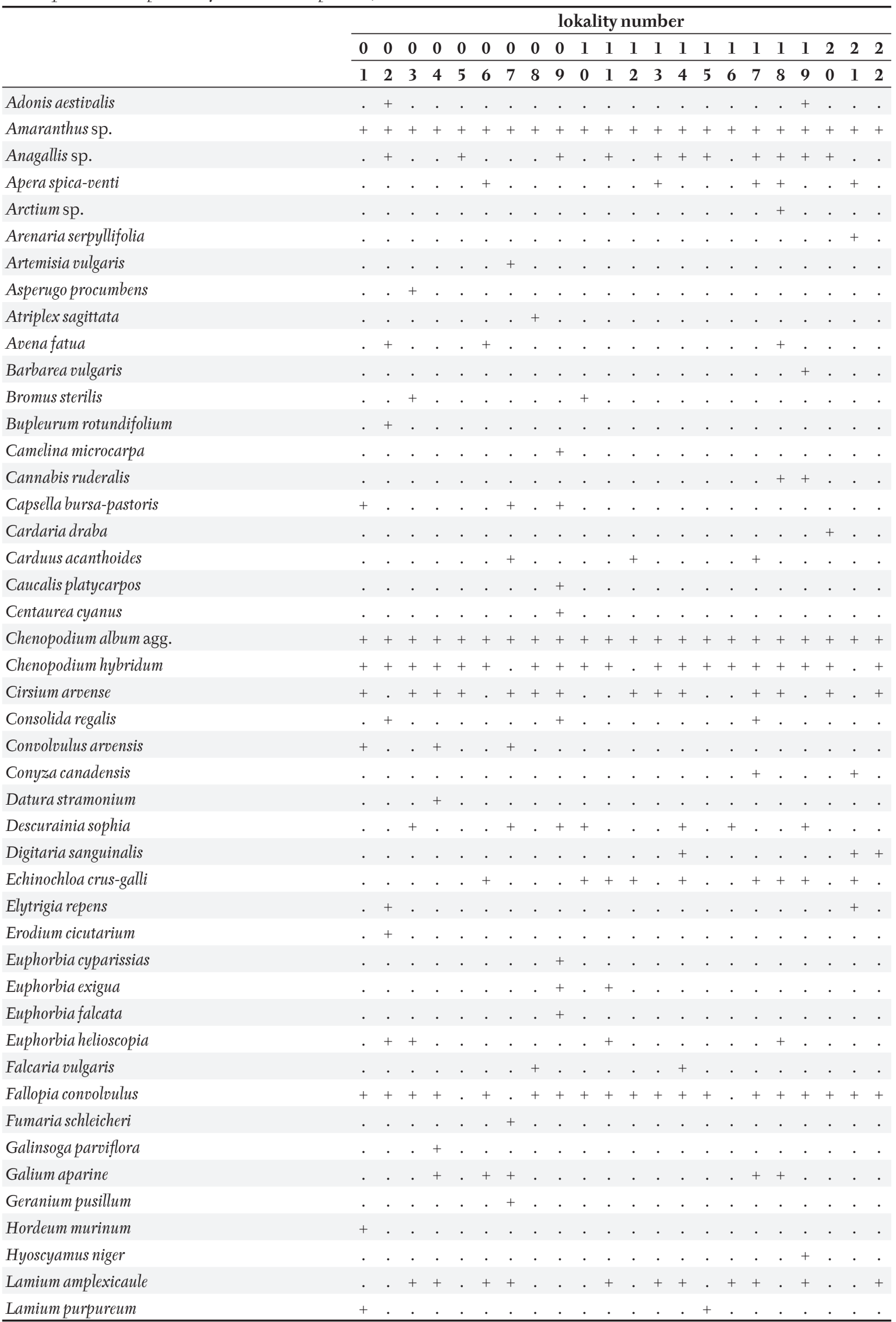




\begin{tabular}{|c|c|c|c|c|c|c|c|c|c|c|c|c|c|c|c|c|c|c|c|c|c|c|c|c|c|}
\hline & \multicolumn{25}{|c|}{ lokality number } \\
\hline & 0 & 0 & $\mathbf{0}$ & 0 & ( & & 0 & 0 & $\mathbf{0}$ & 0 & 1 & 1 & 1 & 1 & & 1 & 1 & 1 & 1 & 1 & 1 & 2 & & 2 & 2 \\
\hline & 1 & 2 & 3 & 4 & 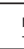 & & 6 & 7 & 8 & 9 & 0 & 1 & 2 & 3 & 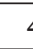 & 4 & 5 & 6 & 7 & 8 & 9 & 0 & & 1 & 2 \\
\hline Lathyrus tuberosus & . & . & . & . & 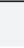 & & . & . & . & + & . & + & . & . & 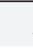 & . & . & . & . & . & . & . & . & . & . \\
\hline Medicago lupulina & . & . & . & . & & & . & . & . & . & . & . & . & . & 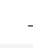 & + & . & . & . & . & . & . & & . & - \\
\hline Mercurialis annua & . & . & + & . & & & . & . & + & + & + & + & . & . & & . & + & + & . & . & + & + & + & . & . \\
\hline Microrrhinuт minus & . & . & . & . & & & . & . & . & + & . & + & . & . & & . & . & . & . & . & . & . & & . & . \\
\hline Onopordum acanthium & . & . & . & . & & & . & . & . & . & + & . & . & . & & . & . & . & . & . & . & . & & . & + \\
\hline Panicum miliaceum subsp. agricola & . & . & . & . & & & . & . & . & . & . & . & . & . & - & + & . & + & . & . & . & . & & . & . \\
\hline Papaver rhoeas & + & + & + & + & . & & + & . & . & + & + & + & . & . & & . & + & . & . & + & + & + & + & . & . \\
\hline Persicaria lapathifolia & . & . & . & + & & & + & . & . & . & . & . & . & . & & . & . & . & . & . & . & . & & . & . \\
\hline Persicaria maculosa & . & . & . & . & & & . & . & . & . & . & . & + & . & & & + & . & . & . & . & . & . & . & . \\
\hline Polygonum aviculare agg. & . & + & + & + & & & + & . & + & + & + & . & . & + & 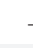 & + & + & . & + & + & + & + & & + & + \\
\hline Resedalutea & . & . & . & . & & & . & . & . & + & . & + & . & . & & . & . & . & . & . & . & . & . & . & . \\
\hline Setaria pumila & . & . & . & . & & & + & . & . & + & + & . & . & . & - & + & . & . & . & . & + & . & & + & . \\
\hline Setaria verticillata & . & . & . & . & & & . & . & . & . & . & . & . & . & - & + & . & . & . & . & . & . & . & . & . \\
\hline Setaria viridis & . & + & . & . & & & + & . & . & + & + & . & . & . & - & + & + & . & + & . & + & . & & + & . \\
\hline Silene noctiflora & . & + & + & . & & & . & . & . & + & + & + & . & + & & . & + & . & . & . & + & + & + & . & . \\
\hline Sinapis arvensis & . & . & + & . & & & . & . & . & + & . & . & . & + & 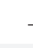 & + & + & . & + & + & . & . & & + & . \\
\hline Sonchus oleraceus & + & . & . & . & & & . & . & . & . & . & . & . & + & & . & . & . & . & . & . & . & & . & . \\
\hline Stachys annua & . & + & . & . & & & . & . & + & + & + & + & . & . & & . & . & . & . & . & + & . & & . & . \\
\hline Stellaria media & . & . & + & + & & & + & + & . & + & . & + & + & + & & . & + & + & + & + & + & + & + & . & + \\
\hline Taraxacum sect. Ruderalia & . & . & . & . & & & . & + & . & . & . & . & . & . & & . & . & . & . & . & . & . & . & . & . \\
\hline Thlaspiarvense & . & . & . & . & & & . & . & . & . & . & . & + & . & & . & + & . & + & . & + & . & & . & . \\
\hline Trifolium arvense & . & . & . & . & & & . & . & . & . & . & . & . & . & & . & . & . & . & . & . & . & & + & . \\
\hline Tripleurospermum inodorum & . & + & + & + & & & + & . & . & + & . & . & + & + & . & + & . & . & + & + & + & + & + & + & + \\
\hline Urtica dioica & . & . & . & . & & & . & + & . & . & . & . & . & . & & . & . & . & . & . & . & . & & . & . \\
\hline Urtica urens & . & . & . & . & & & . & . & . & . & . & . & . & . & & . & . & . & . & . & . & . & . & . & + \\
\hline Valerianella locusta & . & . & . & . & & & . & + & . & . & . & . & . & . & & . & . & . & . & . & . & . & & . & . \\
\hline Veronica arvensis & . & . & . & . & & & . & . & . & . & . & . & . & + & & . & . & . & + & . & . & . & . & . & . \\
\hline Veronica hederifolia agg. & . & + & . & + & & & . & + & . & + & . & . & . & + & & + & + & . & + & + & + & . & & . & . \\
\hline Veronica persica & . & . & . & . & & & . & + & . & . & . & . & . & . & & . & . & . & . & . & . & . & & . & . \\
\hline Veronica polita & . & . & + & . & & & + & . & . & . & + & . & . & . & & . & . & . & + & . & . & . & & . & . \\
\hline Vicia tetrasperma & . & . & . & . & & & - & . & . & + & . & . & . & . & & . & . & . & . & . & . & . & & . & . \\
\hline Viola arvensis & . & + & . & . & & & + & . & . & + & $\cdot$ & + & . & . & & . & + & . & + & + & + & + & + & . & \\
\hline Vulpia myuros & . & . & . & . & 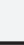 & & . & . & . & . & . & . & . & . & 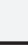 & . & . & . & . & . & . & . & & + & \\
\hline
\end{tabular}


II: Number of seeds and fruits in soil samples and values of Sórensen's indices of similarity [\%]. (Values of similarity of $75 \%$ and more are printed in bold.).

S1 - Similarity between seed bank and vegetation on area where soil sample were taken and in the surroundings.

S2 - Similarity between seed bank and vegetation on area where soil sample were taken.

\begin{tabular}{|c|c|c|c|c|c|c|c|c|c|c|}
\hline \multirow[b]{2}{*}{ locality } & \multicolumn{2}{|c|}{ autumn 1997} & \multicolumn{2}{|c|}{ spring 2002} & \multicolumn{2}{|c|}{ autumn 2002} & \multirow[b]{2}{*}{$\begin{array}{c}\text { species } \\
\text { total }\end{array}$} & \multirow[b]{2}{*}{ S1 } & \multirow[b]{2}{*}{ S2 } & \multirow[b]{2}{*}{$\begin{array}{c}\text { Method of } \\
\text { management }\end{array}$} \\
\hline & $\begin{array}{l}\text { number } \\
\text { of species }\end{array}$ & $\begin{array}{c}\text { number } \\
\text { of } \\
\text { diasporas }\end{array}$ & $\begin{array}{c}\text { number } \\
\text { of species }\end{array}$ & $\begin{array}{c}\text { number } \\
\text { of } \\
\text { diasporas }\end{array}$ & $\begin{array}{c}\text { number } \\
\text { of species }\end{array}$ & $\begin{array}{c}\text { number } \\
\text { of } \\
\text { diasporas }\end{array}$ & & & & \\
\hline 1 & - & - & 9 & 58 & 8 & 63 & 11 & 66.7 & 72.0 & $\mathrm{P}$ \\
\hline 2 & - & - & 17 & 54 & 15 & 50 & 21 & 62.1 & 75.0 & $\mathrm{AE}$ \\
\hline 3 & - & - & 13 & 81 & 14 & 124 & 20 & 86.4 & 86.5 & $\mathrm{AE}$ \\
\hline 4 & 10 & 69 & 13 & 215 & 10 & 124 & 18 & 72.2 & 90.9 & $\mathrm{P}$ \\
\hline 5 & 6 & 25 & 6 & 44 & 7 & 121 & 10 & 58.1 & 74.0 & $\mathrm{AE}$ \\
\hline 6 & - & - & 14 & 85 & 12 & 84 & 18 & 70.8 & 79.1 & $\mathrm{P}$ \\
\hline 7 & - & - & 19 & 527 & 13 & 365 & 19 & 72.7 & 76.2 & $\mathrm{AE}$ \\
\hline 8 & 8 & 116 & 10 & 73 & 10 & 61 & 14 & 51.1 & 64.7 & $\mathrm{AE}$ \\
\hline 9 & 25 & 291 & 27 & 478 & 17 & 356 & 33 & 76.3 & 79.4 & $\mathrm{AE}$ \\
\hline 10 & 13 & 141 & 10 & 69 & 13 & 112 & 19 & 60.0 & 65.2 & $\mathrm{AE}$ \\
\hline 11 & - & - & 14 & 147 & 16 & 93 & 19 & 53.1 & 65.0 & $\mathrm{AE}$ \\
\hline 12 & - & - & 8 & 113 & 9 & 162 & 13 & 64.3 & 64.0 & $\mathrm{P}$ \\
\hline 13 & - & - & 13 & 353 & 11 & 489 & 16 & 64.9 & 70.6 & $\mathrm{P}$ \\
\hline 14 & 16 & 143 & 12 & 153 & 13 & 97 & 22 & 75.0 & 82.4 & $\mathrm{AE}$ \\
\hline 15 & 12 & 50 & 14 & 56 & 13 & 119 & 22 & 56.6 & 73.2 & $\mathrm{AE}$ \\
\hline 16 & 6 & 47 & 9 & 63 & 10 & 46 & 13 & 36.4 & 50.0 & $\mathrm{AE}$ \\
\hline 17 & 18 & 228 & 13 & 71 & 14 & 37 & 27 & 72.5 & 73.3 & $\mathrm{O}$ \\
\hline 18 & 12 & 182 & 16 & 75 & 13 & 69 & 23 & 74.5 & 80.9 & $\mathrm{O}$ \\
\hline 19 & 18 & 42 & 18 & 164 & 20 & 98 & 27 & 60.0 & 67.9 & $\mathrm{P}$ \\
\hline 20 & - & - & 10 & 136 & 14 & 181 & 15 & 60.0 & 70.6 & $\mathrm{AE}$ \\
\hline 21 & - & - & 14 & 510 & 9 & 396 & 16 & 58.3 & 72.2 & $\mathrm{AE}$ \\
\hline 22 & - & - & 9 & 245 & 9 & 53 & 12 & 55.2 & 66.7 & $\mathrm{P}$ \\
\hline
\end{tabular}

III: The qualitative komposition of current vegetation - presence/absence data.

A - on the same area where soil sample were taken.

B - on area where soil sample were taken and in the surroundings.

\begin{tabular}{|c|c|}
\hline & lokality number \\
\hline & 00000000000000000011111111111111111111222222 \\
\hline & 11223344556677889900112233445566778899001122 \\
\hline & АВАВАВАВАВАВАВАВАВАВАВАВАВАВАВАВАВАВАВАВАВАВ \\
\hline Achillea collina & 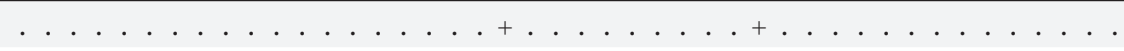 \\
\hline Acinos arvensis & 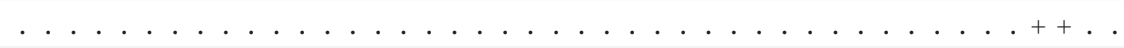 \\
\hline Adonis aestivalis & 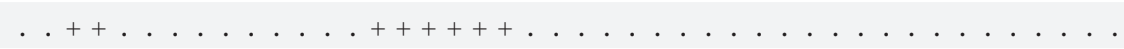 \\
\hline Amaranthus sp. & $++\ldots++++++++++++++++++++++++++\ldots++++++\ldots++++$ \\
\hline Anagallis sp. & $\ldots++\ldots \ldots+\ldots \ldots+++++\ldots \ldots++++\ldots++++++++\ldots+++$ \\
\hline Lycopsis arvensis & 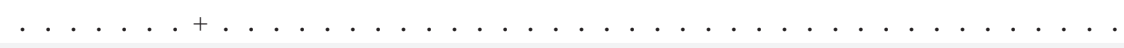 \\
\hline Anthemis arvensis & 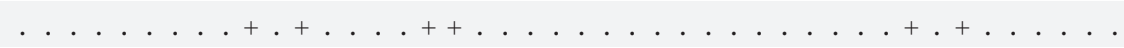 \\
\hline Anthemis austriaca & 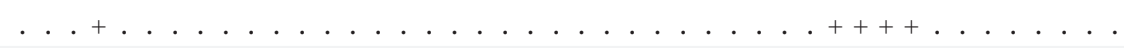 \\
\hline Apera spica-venti & $\ldots \ldots \ldots \ldots++\ldots \ldots \ldots \ldots+\ldots \ldots+\ldots++\ldots \ldots++\ldots$ \\
\hline Arctium sp. & 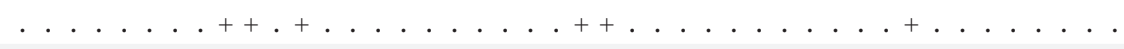 \\
\hline Arenaria serpyllifolia & 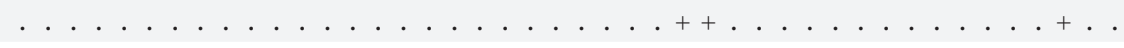 \\
\hline Arrhenatherum alatius & 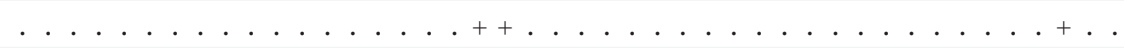 \\
\hline Artemisia vulgaris & $.+\ldots+\ldots \ldots \ldots . \ldots+++\ldots+\ldots++++\ldots \ldots++\ldots+++++\ldots+++++\ldots$ \\
\hline Asperugo procumbens & 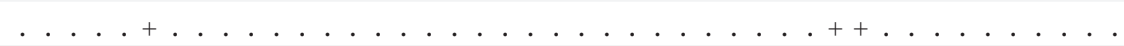 \\
\hline
\end{tabular}




\begin{tabular}{|c|c|}
\hline & lokality number \\
\hline & 00000000000000000011111111111111111111222222 \\
\hline & 11223344556677889900112233445566778899001122 \\
\hline & АВАВАВАВАВАВАВАВАВАВАВАВАВАВАВАВАВАВАВАВАВАВ \\
\hline Atriplex patula & 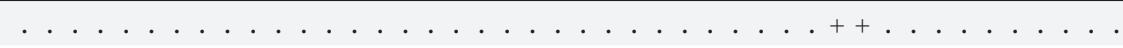 \\
\hline Atriplex sagittata & 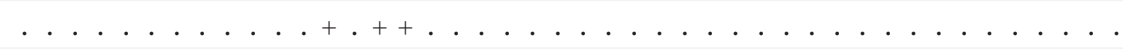 \\
\hline Avenafatua & $.+++\ldots+\ldots+\ldots++\ldots++\ldots+++\ldots+\ldots+\ldots++\ldots \ldots++\ldots \ldots \ldots++$ \\
\hline Barbarea vulgaris & 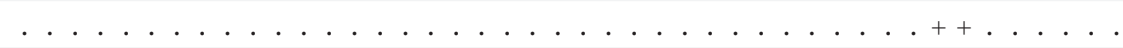 \\
\hline Bromus sterilis & 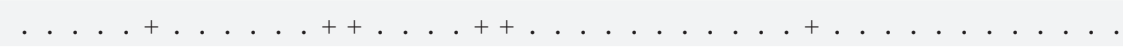 \\
\hline Bromus tectorum & 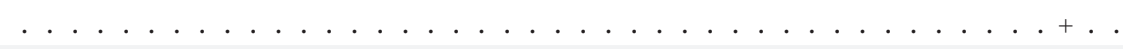 \\
\hline Buglossoides arvensis & 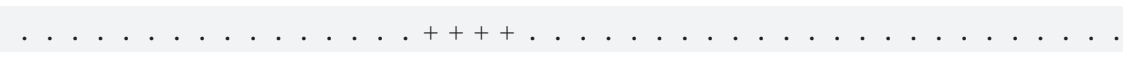 \\
\hline Bupleurum rotundifolium & 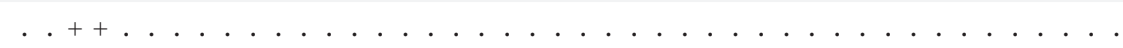 \\
\hline Camelina microcarpa & 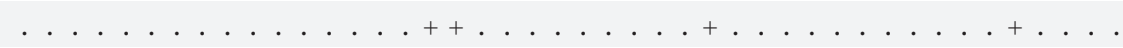 \\
\hline Cannabis ruderalis & 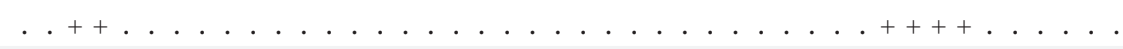 \\
\hline Capsella bursa-pastoris & $++\ldots \ldots \ldots++\ldots++\ldots++\ldots++\ldots \ldots++\ldots+\ldots+\ldots++++\ldots \ldots$ \\
\hline Cardaria draba & 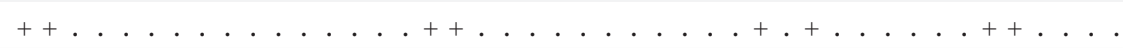 \\
\hline Carduus acanthoides & $\ldots+\ldots \ldots \ldots++\ldots+\ldots \ldots++\ldots++++\ldots+\ldots++\ldots \ldots$ \\
\hline Caucalis platycarpos & 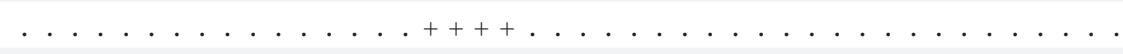 \\
\hline Centaurea cyanus & 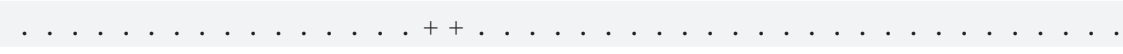 \\
\hline Chenopodium album agg. & $++++++++++++\ldots++++++++++++++++++++++++++++++$ \\
\hline Chenopodium hybridum & $++++++++++++\ldots+++++\ldots++\ldots++++\ldots \ldots \ldots++++\ldots++++$ \\
\hline Chenopodium polyspe & 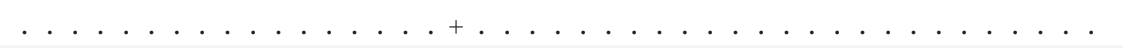 \\
\hline Chondrilla juncea & 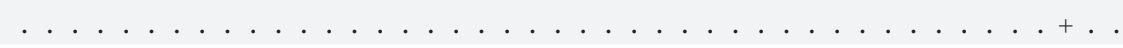 \\
\hline Cirsium arvense & $++\ldots++++++++++++++++++++++++++\ldots++++++++++++$ \\
\hline Cirsium vulgare & 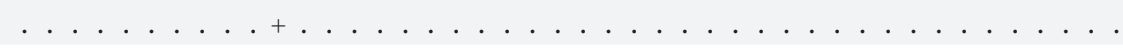 \\
\hline Convolvulus arvensis & $++++++++++++++\ldots+\ldots++++\ldots++\ldots+.+++++\ldots++\ldots+++\ldots+$ \\
\hline Consolida regalis & $\ldots++\ldots \ldots \ldots++\ldots+++++\ldots \ldots++\ldots+\ldots+++++\ldots++\ldots \ldots$ \\
\hline Conium maculatum & 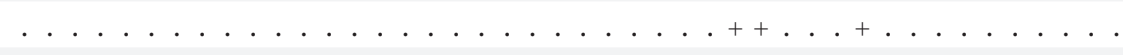 \\
\hline Conyza canadensis & $\ldots+\ldots \ldots \ldots+++\ldots++\ldots \ldots \ldots++\ldots \ldots+\ldots \ldots$ \\
\hline Datura stramonium & 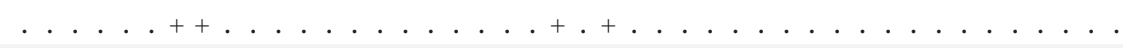 \\
\hline Descurainia sophia & $\ldots+++\ldots . \ldots++\ldots+++++\ldots \ldots++\ldots++++\ldots+++\ldots \ldots$ \\
\hline Digitaria sanguinalis & 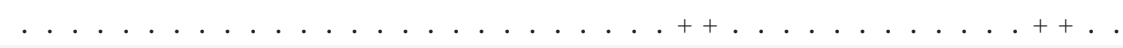 \\
\hline Echinochloa crus-galli & $\ldots \ldots \ldots++++\ldots+\ldots \ldots++++++++\ldots \ldots++++\ldots \ldots++\ldots$ \\
\hline Echium vulgare & 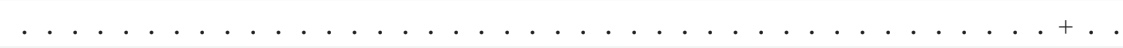 \\
\hline Elytrigia repens & $.+++\ldots+\ldots . \ldots++\ldots+++++\ldots+++++\ldots++\ldots+++++\ldots$ \\
\hline Epilobium tetragonum & 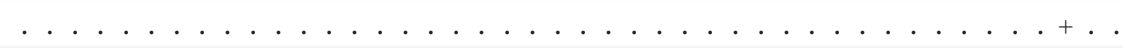 \\
\hline Erodium cicutarium & 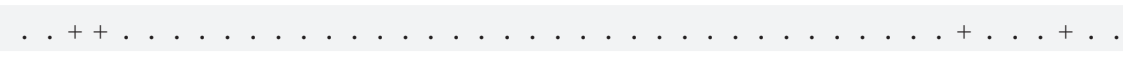 \\
\hline Euphorbia cyparissias & 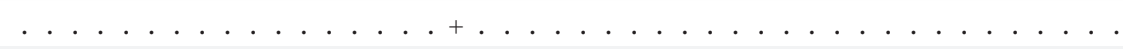 \\
\hline Euphorbia exigua & $\ldots++\ldots \ldots \ldots++\ldots++++++\ldots \ldots \ldots++\ldots \ldots \ldots \ldots$ \\
\hline Euphorbia falcata & 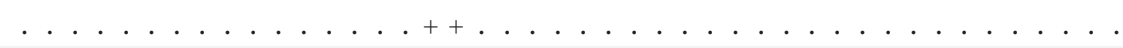 \\
\hline Euphorbia helioscopia & $\ldots++++++\ldots+\ldots \ldots++\ldots \ldots++\ldots \ldots \ldots \ldots \ldots++\ldots++\ldots \ldots$ \\
\hline Euphorbia virgata & 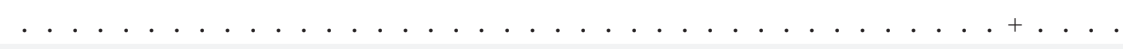 \\
\hline Falcaria vulgaris & 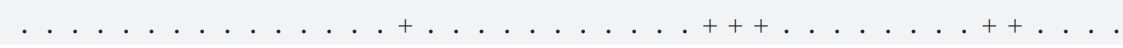 \\
\hline Fallopia convolvulus & $++++++++\ldots++\ldots++++++++\ldots++++++++++++++++++++$ \\
\hline Filago arvensis & 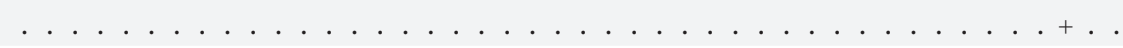 \\
\hline Fumaria officinalis & 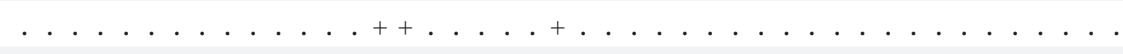 \\
\hline Fumaria schleicheri & 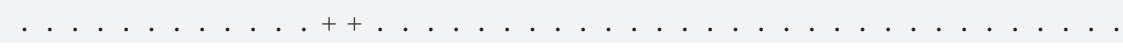 \\
\hline Fumaria vailantii & $\ldots \ldots+\ldots \ldots \ldots+\ldots++\ldots \ldots+\ldots \ldots+\ldots \ldots$ \\
\hline Galinsoga parviflora & 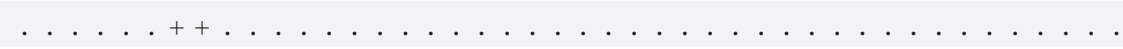 \\
\hline Galium aparine & $++\ldots+\ldots++\ldots++++\ldots++++\ldots+++\ldots \ldots \ldots+++++++\ldots \ldots \ldots$ \\
\hline
\end{tabular}




\begin{tabular}{|c|c|}
\hline & lokality number \\
\hline & 00000000000000000011111111111111111111222222 \\
\hline & 11223344556677889900112233445566778899001122 \\
\hline & АВАВАВАВАВАВАВАВАВАВАВАВАВАВАВАВАВАВАВАВАВАВ \\
\hline Galium spurium & 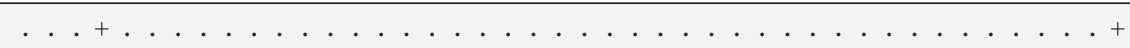 \\
\hline Geranium pusillum & 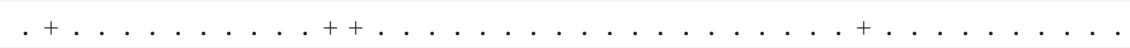 \\
\hline Geranium robertianum & 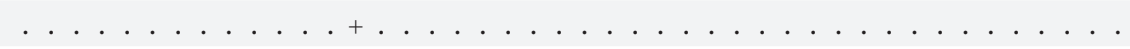 \\
\hline Hordeum тиrinum & 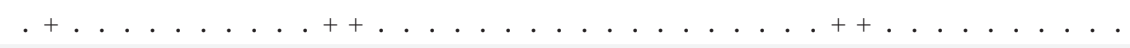 \\
\hline Hyosciamus niger & 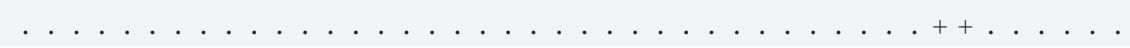 \\
\hline Knautia arvensis & 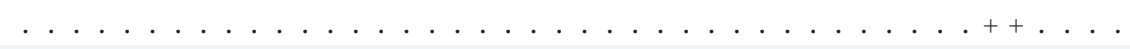 \\
\hline Lactuca serriola & $\ldots \ldots \ldots+\ldots+\ldots \ldots+\ldots \ldots \ldots \ldots+\ldots \ldots$ \\
\hline Lamium amplexicaule & $\ldots++++++\ldots+++++.+++\ldots++\ldots++++\ldots++++\ldots++\ldots \ldots$ \\
\hline Lamium maculc & 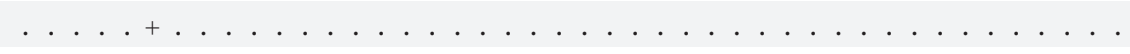 \\
\hline Lamium purpureum & 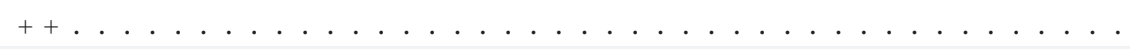 \\
\hline Lappula squarrosa & 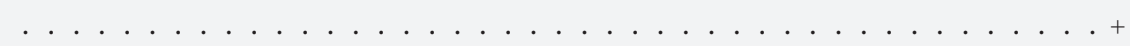 \\
\hline Lathyrus tuberosus & $\ldots+\ldots++++\ldots \ldots+++\ldots+++\ldots \ldots \ldots+\ldots \ldots+\ldots \ldots$ \\
\hline Lolium perenne & $\ldots \ldots \ldots \ldots \ldots \ldots \ldots \ldots \ldots \ldots+\ldots \ldots+\ldots \ldots \ldots$ \\
\hline Matricaria chamomilla & 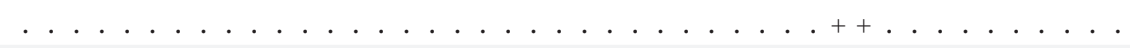 \\
\hline Matricaria discoidea & 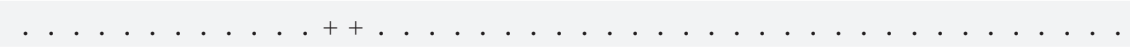 \\
\hline Medicago lupulina & 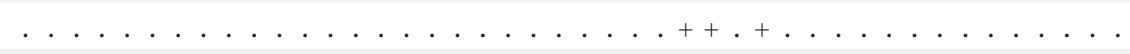 \\
\hline Mercurialis annua & $\ldots \ldots \ldots \ldots+\ldots_{+t+t+t+} \ldots \ldots++\ldots \ldots++\ldots \ldots$ \\
\hline Microrhinum minus & $\ldots \ldots \ldots \ldots+\ldots+\ldots \ldots++\ldots \ldots+\ldots \ldots \ldots$ \\
\hline Myosotis arvensis & 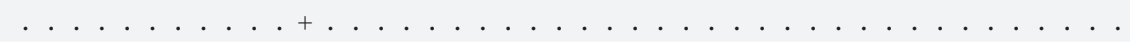 \\
\hline Neslia paniculata & 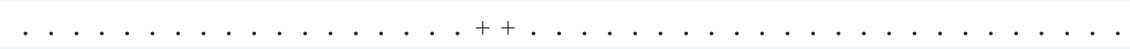 \\
\hline Nigella arvensis & 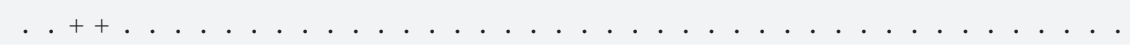 \\
\hline Onopordum acanthium & 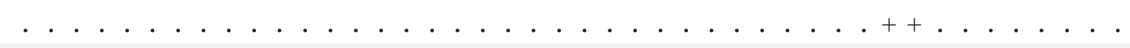 \\
\hline Panicum miliaceum subsp. agricola & 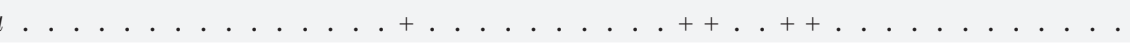 \\
\hline Papaver rhoeas & $++++++++++++\ldots .+++++++\ldots . \ldots+++++++++++++\ldots \ldots$ \\
\hline Persicaria lapathifolia & 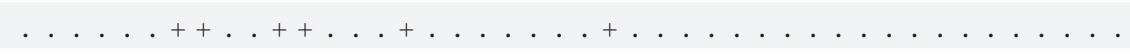 \\
\hline Persicaria maculosa & $\ldots \ldots \ldots \ldots+\ldots \ldots \ldots \ldots+\ldots \ldots \ldots$ \\
\hline Plantago lanceolata & 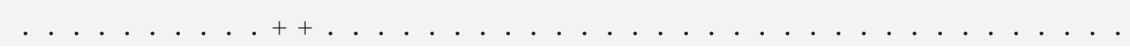 \\
\hline Plantago major & 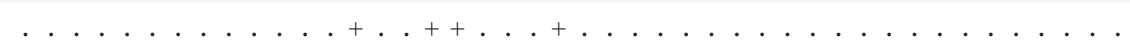 \\
\hline Polygonum aviculare agg. &.+++++++++++++++++++++++++++++++++++++++++++ \\
\hline Resedalutea & 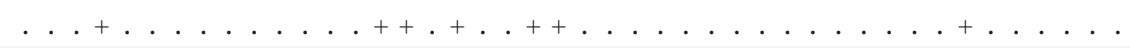 \\
\hline Rubus caesius & 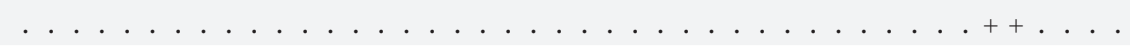 \\
\hline Rumexsp. & 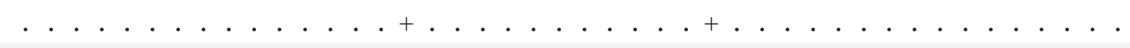 \\
\hline Salvia verticillata & 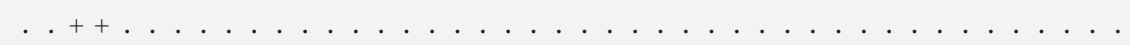 \\
\hline Senecio vulgaris & 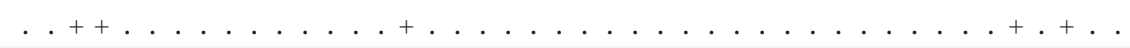 \\
\hline Setaria pumila & $\ldots \ldots \ldots \ldots \ldots \ldots+\ldots++\ldots \ldots+\ldots$ \\
\hline Setaria verticillata & 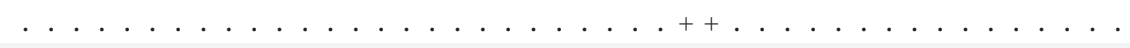 \\
\hline Setaria viridis & $\ldots++\ldots \ldots \ldots++\ldots \ldots++++\ldots \ldots++++\ldots \ldots++\ldots \ldots++\ldots$ \\
\hline Silene latifolia & 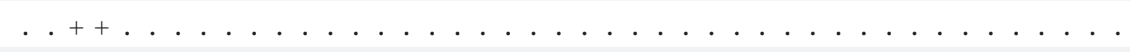 \\
\hline Silene noctiflora & $\ldots++++\ldots \ldots \ldots \ldots++++\ldots \ldots+\ldots++\ldots \ldots \ldots++++++$ \\
\hline Sinapis arvensis & $\ldots+++\ldots \ldots \ldots++++++\ldots \ldots++++\ldots+++++\ldots \ldots$ \\
\hline Sonchus arvensis & 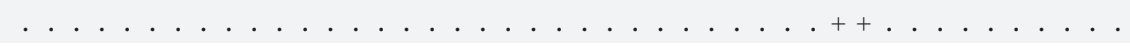 \\
\hline Sonchus asper & 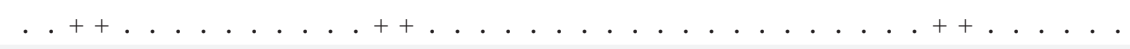 \\
\hline Sonchus oleraceus & 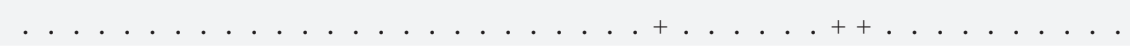 \\
\hline Stachys annua & $\ldots++\ldots \ldots \ldots \ldots++++++\ldots \ldots++++\ldots \ldots \ldots \ldots$ \\
\hline Stellaria media & $\ldots \ldots++\ldots++++++\ldots \ldots \ldots+++++++++++++++++++++\ldots++$ \\
\hline Taraxacum sect. Ruderalia & $\ldots \ldots \ldots \ldots++\ldots++\ldots \ldots \ldots++++\ldots \ldots \ldots \ldots+\ldots+\ldots \ldots+$ \\
\hline
\end{tabular}




\begin{tabular}{|c|c|}
\hline & lokality number \\
\hline & 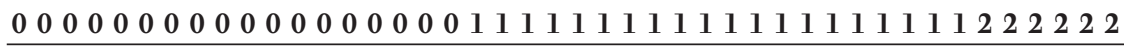 \\
\hline & 11223344556677889900112233445566778899001122 \\
\hline Thlaspiarvense & . . . . . . . ++ . . . . . . +... ..........+++++++++ \\
\hline Trifolium arvense & . . . . . . . . . . . . . . . . . . . + + \\
\hline Urtica dioica & . . . . . . . . . . . . . . . + . . . . . \\
\hline Urtica urens & . . . . . . . + . . . . . . . . . . . . . . . \\
\hline Veronica hederifolia agg. & 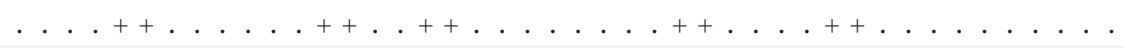 \\
\hline Veronica arvensis & . . . . . . . . . . . . . . ++++ +. . ++ +....... \\
\hline Viola arvensis &................$++++++++++++++++++++++++\ldots$ \\
\hline Vulpia myuros & . . . . . . . . . . . . . . . . . . . +. \\
\hline Xanthium strumarium & . . . . . . . . . . . . . . . . . . . . . . . \\
\hline
\end{tabular}

\section{SUMMARY}

Comparisons were made between the seed bank and the aboveground vegetation of field weeds. The objectives of the present study are the following:

1. Basing on comparisons between the current vegetation and the soil seed bank to evaluate the present state of field weed associations.

2. Compare sites under various methods of management.

For our study we selected a territory in South Moravia between the river Dyje and the Austrian border. On the basis of observations of the vegetation during the vegetation period we selected 22 localities where we assessed the similarity between the soil seed bank and the aboveground vegetation based on data of their presence/absence. Values of Sörensen's indices of similarity showed that the qualitative similarity between the seed bank and current vegetation was relatively high. Maximal differences between the seed bank and vegetation were discovered in fields managed by agricultural enterprises, less on private farms and least of all on organic farms. Detrended correspondence analysis (DCA) showed that pictures from private farms and organic farms were very much alike.

In 1996 to 2002 for better detection of the current situation of segetal associations, 154 phytosociological relevés were recorded in the area under study. They were subjected to canonical correspondence analysis (CCA) where the following environmental variables were entered: method of management (agricultural enterprise, private farms or organic farms), type of produced crop (cereal, maize, root crop, oil plant, fodder crop, vineyard, other) and the season (continuous variable with values from 0 to 12). Using the permutation test (Monte Carlo test) we tested the significance of the variable environments. The Monte Carlo test showed that the most significant variable of the environment was the season, followed by some crops and only then the method of management. The assumption that the most species-abundant plant associations with a considerably higher proportion of rare and endangered species would develop in fields managed organically or on small private farms was not confirmed. It seems more likely that such associations are bound to places where the possibilities of applying chemical substances are limited, i.e. in the vicinity of nature reserves or nearby the state border. The 15 most common field weeds are: Tripleurospermum inodorum, Papaver rhoeas, Chenopodium album, Convolvulus arvensis, Cirsium arvense, Stellaria media, Polygonum aviculare, Amaranthus retroflexus, Capsella bursa-pastoris, Artemisia vulgaris, Fallopia convolvulus, Viola arvensis, Consolida regalis, Descurainia sophia, Galium aparine. at sites that are not very influenced by chemical sprays do we also see rare and endangered species: Adonis aestivalis, Anagallis foemina, Bupleurum rotundifolium, Caucalis platycarpos, Centaurea cyanus, Euphorbia falcata, Galium spurium, Kickxia elatine, Nigella arvensis, Silene noctiflora. The most frequent weeds occurring in the seed bank on the monitored localities were Chenopodium album agg., Amaranthus sp., Fallopia convolvulus, Chenopodium hybridum, Polygonum aviculare agg., Stellaria media, Tripleurospermum inodorum, Cirsium arvense and Papaver rhoeas, Anagallis sp. In addition to these common widespread weeds the occurrence of rare and endangered species was also found in the seed bank, such as Adonis aestivalis, Bupleurum rotundifolium, Caucalis platycarpos, Centaurea cyanus, Hyosciamus niger, Silene noctiflora and Vulpia myuros. 


\section{Acknowledgement}

I wish to express my thanks to all my colleagues for their valuable suggestions and advice, particularly to Zdeňka Lososová and Vladimír Řehořek.

\section{REFERENCES}

FRAHM, J. P. and FREY, W., 1992: Moosflora. Stuttgart: Verlag Eugen Ulmer, s., ISBN 38-2521-250-5.

KUBÁT, K. et al., 2002: Klíc ke kvètené České republiky. Praha: Academia, 927 s., ISBN 80-200-0836-5.

LOSOSOVÁ, Z. et al., 2004: Weed vegetation of arable land in Central Europe: Gradients of diversity and species composition. Journal of Vegetation Science, 15: 415-422. ISSN 1100-9233.

MAYOR, J. P. and DESSAINT, F., 1998: Influence of weed management strategy on soil seed bank diversity. Weed research, 38: 95-195. ISSN 0043-1737.
StatSoft, lnc. (2001): STATISTICA (data analysis software system). Version 7. - URL [http://www.statsoft.com].

TICHÝ, L., 2002: JUICE, software for vegetation classification. J. Veg. Sci. 13: 451-453. ISSN 1100-9233.

BRAAK, C. J. F. and ŠMILAUER, P., 1998: CANOCO reference manual and user's guide to Canoco for Windows. Software for Cannonical Community Ordination (version 4). Wageningen: Centre of Biometry.

WARR, S. J., KENT, M. and THOMPSON, K., 1994: Seed bank composition and variability in five woodlands in South-West England. Journal of Biogeography, 21: 151-168. ISSN 0305-0270. 
